\title{
Preliminary results of topical hepatic hypothermia in a model of liver ischemia/ reperfusion injury in rats
}

\author{
Emilio Elias ABD0 ${ }^{1,2}$, Estela Regina Ramos FIGUEIRA ${ }^{1,2}$, Joel Avancini ROCHA FILH0 ${ }^{2,3}$, Eleazar CHAIB ${ }^{2,4}$, \\ Luiz Augusto Carneiro D'ALBUQUERQUE ${ }^{2,4}$ and Telesforo BACCHELLA ${ }^{1,2}$
}

ABSTRACT - Background - Ischemia/reperfusion causes organ damage but it is mandatory in hepatic transplantation, trauma and other complex liver surgeries, when Pringle maneuver is applied to minimize bleeding during these procedures. It is well known that liver ischemia/reperfusion leads to microcirculatory disturbance and cellular injury. In this setting hypothermia is known to reduce oxygen demand, lowering intracellular metabolism. Objective - To evaluate the effects of hypothermia in liver ischemia/reperfusion injury, using a new model of topic isolated liver hypothermia. Methods - We used male Wistar rats weighting about 250 grams, kept in ad libitum feeding regime and randomly divided into two groups of nine animals: 1) Normothermic group, rats were submitted to normothermic ischemia of the median and left hepatic lobes, with subsequent resection of right and caudate lobes during liver reperfusion; and 2) Hypothermic group, rats were submitted to liver ischemia under hypothermia at $10^{\circ} \mathrm{C}$. Liver ischemia was performed for 45 minutes. The animals were euthanized 48 hours after liver reperfusion for blood and liver tissue sampling. Results - The transaminases analyses showed a significant decrease of AST and ALT in Hypothermic group $(\mathrm{P}<0.01)$ compared to Normothermic group $(1403 \pm 1234$ x $454 \pm 213$ and $730 \pm 680$ x $271 \pm 211 \mathrm{U} / \mathrm{L}$, respectively). Histology showed severe necrosis in $50 \%$ and mild necrosis in $50 \%$ of cases in Normothermic group, but severe necrosis in $10 \%$ and mild or absent necrosis $90 \%$ of the cases in hypothermic group. Conclusion - A simplified model of liver ischemia/reperfusion that simulates orthotopic liver autotransplantion was demonstrated. Topical hypothermia of isolated hepatic lobules showed liver protection, being a viable and practical method for any kind of in vivo liver preservation study.

HEADINGS - Ischemia. Reperfusion injury. Liver diseases, surgery. Liver transplantation. Induced hypothermia.

\section{INTRODUCTION}

The complex liver surgical procedures such as liver resections requires occlusion of the vascular pedicle, by clamping, to minimize bleeding and allow the planned procedure, characterizing a process of ischemia/reperfusion (IR) injury, which occurs also compulsory in liver transplantation ${ }^{(16)}$. However, other postoperative injuries are observed resulting from this process. On the other hand, topical hepatic hypothermia showed to attenuate pulmonary injury after hepatic $\operatorname{IR}^{(15)}$.

Although the exact mechanism of liver injury remains unclear, it is known through important studies, that IR injury is manifested by the release of free radicals derived from oxygen, uncontrolled calcium influx, depletion of adenosine triphosphate, mitochondrial dysfunction, activation of lysosomal enzymes and microcirculatory disorders ${ }^{(5,7,8,12,13,20,22)}$. Hypothermic ischemia in the field of experimental liver surgery was first employed in 1953, for a period of 20 minutes without observing hepatic injury ${ }^{(18)}$.
The process of removing the bloodstream from the liver as part of the surgical procedure with a therapeutic purpose, as in the extensive hepatic resections or transplantation, leads to a cellular injury condition that can leads to the impairment of the organ and in the case of transplantation, sometimes, forcing retransplantation with its consequences ${ }^{(11)}$. One of the means used to reduce liver damage is its cooling to temperatures able to decrease the metabolic demand, providing increased survival time until liver reperfusion, this feature is required to preserve the organ to be transplanted ${ }^{(14)}$. The main benefit of liver hypothermia is to reduce oxygen demand by the organ. Hypothermia of liver surface may increase ischemic tolerance time up to 90 minutes of ischemia, even without raising the intracellular calcium $^{(23)}$. Furthermore, there is a reduction of hepatic necrosis, infiltration of polymorph nuclear cells, TNF- $\alpha$ and, consequently, attenuation of lung acute injury secondary to liver $\operatorname{IR}^{(15)}$.

The experimental models that reproduce the liver transplantation procedure consist of organ removal for subsequent reimplantation, which is extremely complex and difficult to perform

${ }^{1}$ Hospital das Clínicas, Universidade de São Paulo, Faculdade de Medicina, Departamento de Gastroenterologia, Divisão de Cirurgia Digestiva, São Paulo, SP, Brasil; ${ }^{2}$ Hospital das Clínicas, Universidade de São Paulo, Faculdade de Medicina, Departamento de Gastroenterologia, Laboratório de Investigação Médica LIM37, São Paulo, SP, Brasil; ${ }^{3}$ Hospital das Clínicas, Universidade de São Paulo, Faculdade de Medicina, Departamento de Cirurgia, Disciplina de Anestesiologia, São Paulo, SP, Brasil; ${ }^{4}$ Hospital das Clínicas, Universidade de São Paulo, Faculdade de Medicina, Departamento de Gastroenterologia, Divisão de Transplante de Fígado e Gastrointestinal, São Paulo, SP, Brasil.

Correspondence: Estela Regina Ramos Figueira. Hospital das Clínicas, Universidade de São Paulo, Faculdade de Medicina, Departamento de Gastroenterologia. Av. Dr. Arnaldo, 455, $3^{\circ}$ andar, LIM-37, sala 3222 - CEP: 01246-903 - São Paulo, SP, Brasil. E-mail: estelafigueira@me.com 
in small animals such as rats, which lends itself to the currently experimental research in view of the legal constraints, difficulties and costs related to experimental work with larger animals. The purpose of this study was to evaluate the effects of hypothermia in liver ischemia/reperfusion injury, using a new simplified model of topic isolated liver hypothermia, comparable to liver autotransplantation, easily reproducible.

\section{METHODS}

Male Wistar rats (University of São Paulo School of Medicine Biological Laboratory) weighing 175-225 g were used for all experiments. Rats were allowed free access to rat chow and water in an environment with controlled temperature between $20^{\circ} \mathrm{C}$ and $23^{\circ} \mathrm{C}$ in a light/dark cycle of 12 to 12 hours, fed with Nuvitab CR 1 (Nuvital Nutrients LTDA, Parana, BR), and hydrated with filtered water ad libitum, before and after surgical procedure. All experiments were conducted in compliance with University of Sao Paulo Institutional Animal Care and Use Committee and Guide for the Care and Use of Laboratory Animals ${ }^{(3)}$. As part of the experiment, a pioneer successful non-lethal model of partial $(70 \%)$ warm hepatic ischemia was performed ${ }^{(1,5)}$.

\section{Experimental design}

Rats were anesthetized by intra-peritoneal injection of ketamine $(30 \mathrm{mg} / \mathrm{Kg}$ rat) and Xylazine $(30 \mathrm{mg} / \mathrm{Kg}$ rat $)$. After midline laparotomy the portal triad was exposed and all structures (hepatic artery, portal vein and bile duct) to the left and median lobes were occluded with a soft vascular clamp (Figure 1A). Preservation of perfusion of the remaining lobes prevented mesenteric venous congestion during ischemia. Immediately after reperfusion, the non-ischemic lobes (right and caudate) were removed by ligation of their pedicle as described previously ${ }^{(5)}$ (Figure 1B).

To achieve about $10^{\circ} \mathrm{C}$ of liver hypothermia during ischemia in the Hypothermic group, a plate of polystyrene was initially placed over the animal to isolate the left lateral and median liver lobes from the right lobes, caudate lobes and animal body, avoiding induction of systemic hypothermia. After occlusion of the portal triad to produce liver ischemia, the isolated left lateral and median lobes were surrounded with $3 \mathrm{~cm}$ length Penrose packs filled with frozen water (Figure 1C). A surface probe (Digital Thermometer MT450/MT-455 from Minipa Eletronics Inc., TX, USA) was placed between median and lateral left lobes to measure the liver core temperature that was maintained at $10^{\circ} \mathrm{C}$. Animals were operated on a heating table, maintaining body temperature between $36^{\circ} \mathrm{C}$ and $37^{\circ} \mathrm{C}$ that was monitored with the rectal digital YSI Precision 4000A Thermometer (YSI Inc., OH, USA). After liver reperfusion, animals were recovered in isolated cages. Forty-eight hours (two days) after reperfusion animals were re-anesthetized for blood collection via cardiac puncture and euthanized by exsanguination. Hepatic injury was assessed in terms of transaminases levels. As biomarkers for liver health, serum alanine aminotransferase (ALT) and aspartate aminotransferase (AST) were measured by automatic analysis. The method adopted was the ultraviolet optimized (Cobas Miras, Roche) according to the International Federation of Clinical Chemistry.

Liver samples of ischemic lobes were collected and prepared for standard hematoxylin and eosin staining. An experienced and blinded pathologist estimated the degree of necrosis in four stages: absent, mild, moderate and severe.

\section{Study groups (Table 1)}

Normothermic group $(n=9)$ : rats were submitted to normothermic partial liver ischemia of left and median lobes for $45 \mathrm{~min}$, with subsequent resection of non-ischemic liver lobes (right and caudate) during the first minutes of reperfusion.

Hypothermic group $(n=9)$ : rats were submitted to hypothermic partial liver ischemia of left and median lobes for $45 \mathrm{~min}$, with subsequent resection at reperfusion of non-ischemic lobes.

TABLE 1. Scheme of study groups

\begin{tabular}{|c|c|c|}
\hline & $\begin{array}{l}\text { Normothermic } \\
\text { group }\end{array}$ & $\begin{array}{l}\text { Normothermic } \\
\text { group }\end{array}$ \\
\hline $\mathrm{N}$ & 9 & 9 \\
\hline Laparotomy & Yes & Yes \\
\hline Partial liver ischemia & $45 \mathrm{~min}$-normothermic & $\begin{array}{l}45 \text { min-hypothermic } \\
\left(10^{\circ} \mathrm{C}\right)\end{array}$ \\
\hline Ischemic liver lobes & Median and left & Median and left \\
\hline Lobe resection & Right and caudate & Right and caudate \\
\hline $\begin{array}{c}\text { Tissue and blood } \\
\text { sampling, and animal } \\
\text { euthanasia }\end{array}$ & After $48 \mathrm{~h}$ & After $48 \mathrm{~h}$ \\
\hline
\end{tabular}
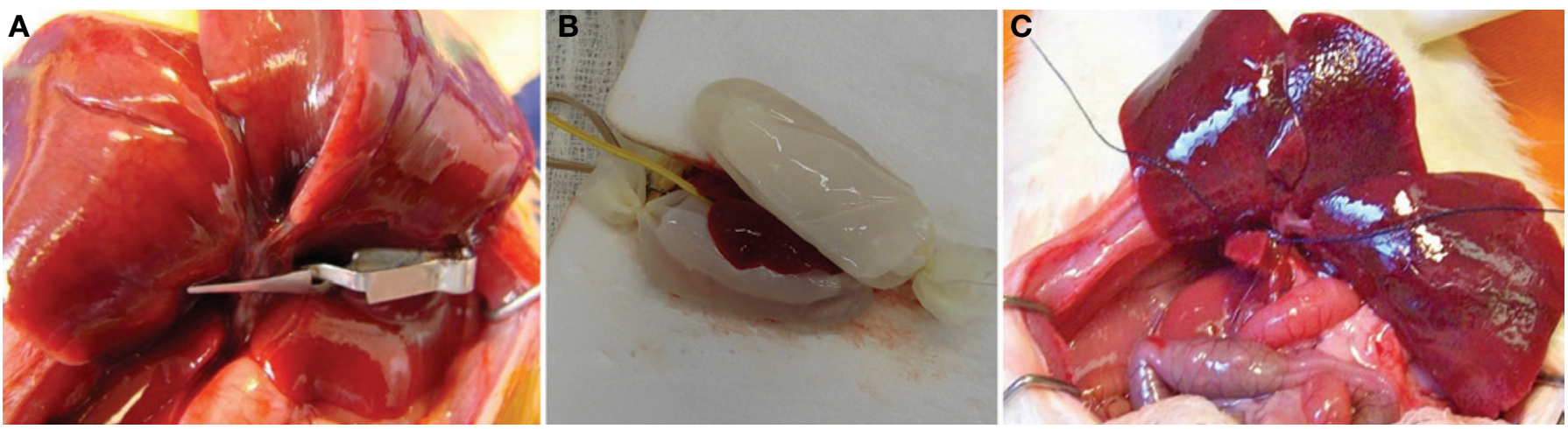

FIGURE 1. Left lateral and median liver lobes occluded with a soft vascular clamp (A). Left lateral and median lobes isolated from the animal with a plate of polystyrene, and placed between two Penrose packs filled with crushed ice (B). Resection of the non-ischemic right and caudate liver lobes (C). 


\section{Statistical analysis}

Results of AST and ALT were expressed as mean and standard deviation, and statistical analysis was performed using the Mann Whitney test. Results of necrosis were showed as grades 0 to 1 , and grades 2 to 3 , and were expressed as percentage. The statistical analysis was performed using Fisher's exacted test. The Graphpad prism 6.0 was used to perform calculations.

\section{RESULTS}

\section{Liver transaminases}

The procedure of liver ischemia associated to hypothermia was completed satisfactorily in nine subjects without any intercurrence.

The transaminases analyses (Figure 2) showed a significant decrease of AST and ALT in the Hypothermic group compared to Normothermic group ( $454 \pm 213$ vs $1403 \pm 1234 \mathrm{UI} / \mathrm{L}, P=0.0094$, and $271 \pm 211$ vs $730 \pm 680 \mathrm{U} / \mathrm{L}, P=0.0065$, respectively).

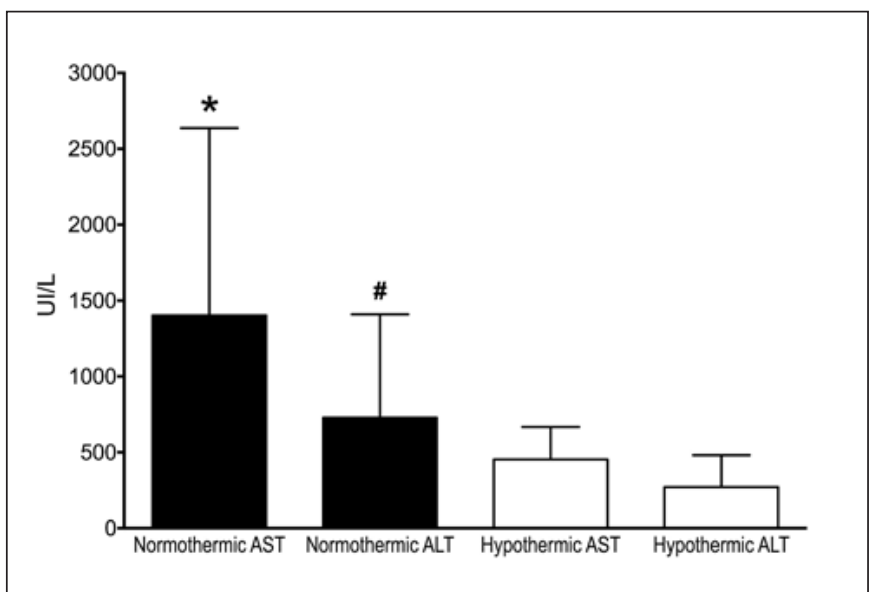

FIGURE 2. Serum levels of AST and ALT $48 \mathrm{~h}$ after reperfusion. Normothermic, animals subjected to $45 \mathrm{~min}$ of warm partial liver ischemia. Hypothermic animals subjected to $45 \mathrm{~min}$ of hypothermic partial liver ischemia. Data are presented with means \pm standard deviation, $n=9$ per group. $* P=0.0092$ compared to Hypothermic AST; ${ }^{*} P=0.0065$ compared to Hypothermic ALT. Mann-Whitney test.

\section{Liver necrosis}

Evaluation of liver necrosis showed increased necrosis (grade 2 to 3 ) in $50 \%$ of cases in the Normothermic group compared to $10 \%$ in the Hypothermic group $(P=0.0704)$.

To overcome the complexity of classical models of liver autotransplantation in experimental studies, to evaluate ischemia/ reperfusion (IR) injuries and effects of liver hypothermia during liver ischemia, and to define new strategies for organ preservation $^{(2,9,21)}$, a simplified surgical procedure was proposed for small animals such as the rat. Instead of excluding the whole liver from its vascularization, which involves difficult management of the organ and techniques to overcome the problem of interrupting portal circulation that require high skilled researchers able to implant the liver in few minutes.

As described, in our proposed model, the ischemia period is achieved by clamping the selected pedicle of median and left lateral segments of the liver. These leads to ischemia of about $70 \%$ to $80 \%$ of the liver with preservation of portal vein flow, avoiding splanchnic congestion. After this ischemic period, when starting liver reperfusion, the non-ischemic lobes that maintained portal circulation are excised as described ${ }^{(5)}$. Animals were evaluated with the liver subjected to global ischemia without influence of non-ischemic lobes in the reperfusion period. In a previous study of our laboratory it was demonstrated that animals submitted to warm ischemia with resection of ischemic lobes presented a 7-day survival between $12.5 \%$ and $50 \%{ }^{(5)}$, indicating this is a suitable model to evaluate survival that is dependent solely on the remaining $70 \%$ liver subjected to ischemia. On the other hand, according to our previous experience, 1 hour of partial liver ischemia with preservation of non-ischemic lobes during reperfusion leads to very feel casualties hampering the survival analysis and decreasing transaminases levels ${ }^{(4,19)}$.

We demonstrated that this model is appropriated to study the effects of profound hypothermic liver ischemia. The AST and ALT were decreased by $65 \%$ in the hypothermic group $48 \mathrm{~h}$ after reperfusion. And the incidence of necrosis was 5 times higher in the normothermic IR group. In 2000, Patel et al. ${ }^{(15)}$, Imakita et al. ${ }^{(6)}$, Quireze Jr et al. ${ }^{(17)}$ and, more recently, Longo et al. ${ }^{(10)}$ achieved cephalad liver protection although applying only moderate hypothermia around $20^{\circ} \mathrm{C}$ to $26^{\circ} \mathrm{C}$. Thus topical hypothermia protects the liver against ischemia and may play a role in some cases of hepatic resection performed with temporary inflow occlusion. On the other hand, profound liver hypothermia as shown in this research is more suitable for evaluation of real procedures of liver preservation as occur in liver transplantation and autotransplantation.

Our results confirm that profound hypothermia is a protective factor against irreversible changes to liver cells caused by the IR process. In conclusion, this model of topical liver hypothermia in rats provides a way to evaluate the effects and mechanisms of hypothermia without influence of other variables as occur in liver transplantation, preservation solutions, and non-ischemic liver lobes.

\section{ACKNOWLEDGEMENTS}

We thank the physicians, Dr. Paulo Andre Olivieri and Dr. Daniel Reis Waisberg, who helped to perform part of the experiments.

\section{Authors' contributions}

Abdo EE, Bacchella T, and Figueira ERR, were involved in study design and performing the experiments. Abdo EE, Figueira ERR and Rocha Filho JA were involved in data analysis and writing the manuscript. Chaib E and D'Albuquerque LAC contributed to the study design, the manuscript writing and performed the manuscript revision. 
Abdo EE, Figueira ERR, Rocha Filho JA, Chaib E, D’Albuquerque LAC, Bacchella T. Resultados preliminares de hipotermia tópica do fígado em modelo de isquemia/reperfusão hepática em ratos. Arq Gastroenterol. 2017;54(3):246-9.

RESUMO - Contexto - A isquemia/reperfusão leva a grave lesão de órgãos, mas ocorre obrigatoriamente no transplante hepático, no trauma e em outras cirurgias hepáticas complexas, quando a manobra de Pringle é aplicada com o intuito de minimizar o sangramento durante os procedimentos. É bem conhecido que a isquemia/reperfusão do fígado leva a distúrbios microcirculatórios e lesões celulares. Neste cenário, a hipotermia é conhecida por reduzir a demanda de oxigênio, diminuindo o metabolismo intracelular. Objetivo - Avaliar os efeitos da hipotermia na lesão de isquemia/reperfusão hepática utilizando-se um novo modelo de hipotermia isolada do fígado. Métodos - Utilizaram-se ratos Wistar do sexo masculino com peso aproximado de 250 gramas, mantidos em regime de alimentação ad libitum e divididos aleatoriamente em dois grupos de nove animais: 1) Grupo Normotérmico - os ratos foram submetidos a isquemia normotérmica dos lobos hepáticos mediano e esquerdo, com posterior ressecção dos lobos direito e caudado durante a reperfusão hepática; e 2) Grupo Hipotérmico - os ratos foram submetidos a isquemia hepática sob hipotermia a $10^{\circ} \mathrm{C}$. A isquemia hepática foi realizada durante 45 minutos. Os animais foram sacrificados 48 horas após a reperfusão hepática para coleta de sangue e tecido hepático para análise. Resultados - As transaminases AST e ALT apresentaram diminuição significativa no grupo Hipotérmico $(P<0,01)$ em relação ao grupo Normotérmico (1403 \pm 1234 x $454 \pm 213$ e $730 \pm 680$ x 271 \pm 211 U/L, respectivamente). A histologia mostrou necrose grave em $50 \%$ e necrose leve em $50 \%$ dos casos no grupo Normotérmico, porém, necrose grave em $10 \%$ e necrose leve ou ausente em $90 \%$ dos casos no grupo Hipotérmico. Conclusão - Foi demonstrado modelo simplificado de isquemia/reperfusão do fígado que simula o autotrasplante de fígado. A hipotermia tópica dos lóbulos hepáticos isolados mostrou proteção do fígado a ischemia/reperfusão, sendo um método viável e prático para qualquer tipo de estudo de preservação hepática in vivo.

DESCRITORES - Isquemia. Traumatismo por reperfusão. Hepatopatias, cirurgia. Transplante de fígado. Hipotermia induzida.

\section{REFERENCES}

1. Abdo EE, Cunha JE, Deluca P, Coelho AM, Bacchella T, Machado MC. Protective effect of N2-mercaptopropionylglycine on rats and dogs liver during ischemia/ reperfusion process. Arq Gastroenterol. 2003;40:177-80.

2. Chi X, Guo N, Yao W, Jin Y, Gao W, Cai J, et al. Induction of heme oxygenase-1 by hemin protects lung against orthotopic autologous liver transplantation-induced acute lung injury in rats. J Transl Med. 2016;14:35.

3. Commission on Life Sciences NRC. Institute of Laboratory Animal Resources 7thedition ed. Washington, D.C.: National Academy Press, 1974.

4. Figueira ER, Bacchella T, Coelho AM, Sampietre SN, Molan NA, Leitao RM, et al. Timing-dependent protection of hypertonic saline solution administration in experimental liver ischemia/reperfusion injury. Surgery. 2010;147:415-23.

5. Figueira ER, Rocha-Filho JA, Nakatani M, Buto MF, Tatebe ER, Andre VO, et al. Hepatic ischemic preconditioning increases portal vein flow in experimental liver ischemia reperfusion injury. Hepatobiliary Pancreat Dis Int. 2014;13:40-7.

6. Imakita M, Yamanaka N, Kuroda N, Kitayama Y, Okamoto E. Does topical cooling alleviate ischemia/reperfusion injury during inflow occlusion in hepatectomy? Results of an experimental and clinical study. Surg Today. 2000;30:795-804.

7. Itasaka H, Suehiro T, Wakiyama S, Yanaga K, Shimada M, Sugimachi K. The mechanism of hepatic graft protection against reperfusion injury by prostaglandin E1. Surg Today. 1999;29:526-32.

8. Khandoga A, Enders G, Biberthaler P, Krombach F. Poly(ADP-ribose) polymerase triggers the microvascular mechanisms of hepatic ischemia-reperfusion injury. Am J Physiol Gastrointest Liver Physiol. 2002;283:G553-560.

9. Liu X, He C, Huang T, Gu J. Development of a New Technique for Reconstruction of Hepatic Artery during Liver Transplantation in Sprague-Dawley Rat. PLoS One 2015;10:e145662.

10. Longo L, Sinigaglia-Fratta LX, Weber GR, Janz-Moreira A, Kretzmann NA, Grezzana-Filho Tde $\mathrm{J}$, et al. Hypothermia is better than ischemic preconditioning for preventing early hepatic ischemia/reperfusion in rats. Ann Hepatol. 2016;15:110-20.

11. Memeo R, Laurenzi A, Pittau G, Sanchez-Cabus S, Vibert E, Adam R, et al. Repeat liver retransplantation: rationale and outcomes. Clin Transplant. 2016;30:312-9.
12. Minor T, Koetting M, Koetting M, Kaiser G, Efferz P, Luer B, et al. Hypothermic reconditioning by gaseous oxygen improves survival after liver transplantation in the pig. Am J Transplant. 2011;11:2627-34.

13. Pannen BH. New insights into the regulation of hepatic blood flow after ischemia and reperfusion. Anesth Analg. 2002;94:1448-57.

14. Parsons RF, Guarrera JV. Preservation solutions for static cold storage of abdominal allografts: which is best? Curr Opin Organ Transplant. 2014;19:100-7.

15. Patel S, Pachter HL, Yee H, Schwartz JD, Marcus SG, Shamamian P. Topical hepatic hypothermia attenuates pulmonary injury after hepatic ischemia and reperfusion. J Am Coll Surg. 2000;191:650-6.

16. Pringle JH. V. Notes on the Arrest of Hepatic Hemorrhage Due to Trauma. Ann Surg. 1908;48:541-9.

17. Quireze Jr C, Speranzini MB, Montero EFS, Juliano Y, Novo NF, Nigro AJT. Efeito da hipotermia hepática na isquemia e reperfusão em ratos. Acta Cirurgica Brasileira. 2000;15(S1).

18. Raffucci FL. The effects of temporary occlusion of the afferent hepatic circulation in dogs. Surgery. 1953;33:342-51.

19. Rocha-Santos V, Figueira ER, Rocha-Filho JA, Coelho AM, Pinheiro RS, Bacchella $\mathrm{T}$, et al. Pentoxifylline enhances the protective effects of hypertonic saline solution on liver ischemia reperfusion injury through inhibition of oxidative stress. Hepatobiliary Pancreat Dis Int. 2015;14:194-200.

20. Sakon M, Ariyoshi H, Umeshita K, Monden M. Ischemia-reperfusion injury of the liver with special reference to calcium-dependent mechanisms. Surg Today. 2002;32:1-12.

21. Schoening W, Ariyakhagorn V, Schubert T, Olschewski P, Andreou A, Neuhaus $\mathrm{P}$, et al. Warm HTK donor pretreatment reduces liver injury during static cold storage in experimental rat liver transplantation. Hepatobiliary Pancreat Dis Int. 2015;14:596-602.

22. Wang CY, Ni Y, Liu Y, Huang ZH, Zhang MJ, Zhan YQ, et al. Mild hypothermia protects liver against ischemia and reperfusion injury. World J Gastroenterol. 2005;11:3005-7.

23. Yamanaka N, Dai CL, Okamoto E. Historical evolution of hypothermic liver surgery. World J Surg. 1998;22:1104-7. 